\title{
Proposed Competency Model for Technical and Vocational Education and Training (TVET) Lecturers Teaching in Technical Colleges, Bauchi State in Perspective
}

\author{
Mohammed Adamu Hamisu ${ }^{1}$, Kahirol Mohd Salleh ${ }^{2}$, Lai Chee Sern ${ }^{2}$, \\ Babayo Yakubu Adamu ${ }^{1}$, Kulu Gambo ${ }^{1}$
}

\author{
${ }^{1}$ Abubakar Tatari Ali Polytechnic Bauchi \\ Amadu Bello Way, Bauchi Town, P. M. B. 0094, Bauchi State, Nigeria \\ ${ }^{2}$ Universiti Tun Hussein Onn Malaysia \\ 101 Beg Berkunci, Parit Raja, Batu Pahat, Johor, 86400, Malaysia
}

DOI: $10.22178 /$ pos. $26-7$

LCC Subject Category:

LB1805-2151

Received 15.08.2017

Accepted 20.09.2017

Published online 27.09.2017

Corresponding Author:

Mohammed Adamu Hamisu

mohamsfulani2000@gmail.com

(C) 2017 The Authors. This article is

licensed under a Creative Commons

Attribution 4.0 License @) (1)

\begin{abstract}
Countless issues have been taking place in tertiary institutions including technical colleges of Bauchi State, which give rise to the need for continuous learning and updating competencies of lecturers teaching in technical colleges of all ages. The purpose of this paper is to propose the competency model of TVET lecturers by investigating the competency needs in technical colleges of Bauchi State. Primary data were collected using questionnaires to reveal the perceptions of thirty TVET lecturers based on their competency needs in three categories of technical colleges in Bauchi State. The result shows that the TVET lecturers perceived all the twenty-five competencies as important and the findings also show the accepted Cronbach's Alpha. The paper concerns on only TVET lecturers perceptions on competency needs in their respective colleges. The paper provides an important pilot analysis on proposed competency model of TVET lecturers to enable further analysis in the area to be carried out.
\end{abstract}

Keywords: competency; TVET lecturers; technical colleges.

\section{INTRODUCTION}

A lot of challenges have been taking place in the global academic arena including technical colleges of Bauchi State, which resulted in the need for continuous learning and updating competencies of lecturers across all ages [24]. Therefore, the technical colleges of Bauchi State need to have competent TVET lecturers teaching in technical colleges by ensuring effective education, training and preparation are in place. In order to be among the world players, colleges need to provide competent lecturers with new advance skills so that to meet the challenges of real time in their respective colleges [31]. However, Lack of competency in technical colleges can bring more challenges which required new ways to accomplish competence and employability [32]. It is more valuable for lecturers to develop and improve their workability, capability and skills thoroughly especially for TVET lecturers [4].
Subsequently, competency comprises required ability, skills, knowledge, attitude or behaviour possessed by employee in order to perform a task effectively and efficiently [6].

Not much has been done to re-examine the determinants for the delivery of the TVET policy in Bauchi State. This has left the challenges unattended to, such as poor recognition from members of the societies, outdated instructional facilities for teaching, lack of good linkages with industries, inadequate financing, lack of staff, and the worst among others is the shortage in terms of quality delivery which make the prospect of development even more difficult [21, 22, 23].

In view of the above, a capacity of lecturers teaching in technical colleges is a critical factor in the TVET delivery. While much has been said about funding, infrastructure, instructional materials and other equipment, but there is insufficient investigation on the competencies of TVET lecturers teaching in technical colleges of Bauchi 
State. In other words very little or no research was found in the literature on issues of competencies of TVET lecturers teaching in technical colleges of Bauchi State. Thus, the purpose of this research is to investigate the competency needs of TVET lecturers teaching in technical colleges and to propose the needed competency model for TVET lecturers teaching in technical colleges of Bauchi State.

The main objectives of this research are as follows: 1) To determine the TVET lecturers' perception on competency needs in teaching technical colleges in Bauchi State; 2) To propose the needed competency model for TVET lecturers teaching in technical colleges of Bauchi State.

\section{REVIEW OF LITERATURE}

\section{Technical and Vocational Education and Training (TVET) Lecturer}

The word lecturer or teacher both in general education and in TVET are the backbone of education and training system. Therefore, TVET lecturers can be consider as the tool or instrument of preparing citizen to be responsible in life. The TVET lecturer or teacher programme is offered in technical colleges. Students who enrolled in these programme are prepared in different areas of studies in TVET which is aimed at producing competent TVET lecturers or teachers in the schools after graduation from their respective colleges [35].

The curriculum of TVET is based on a career title which plays a significant role in producing skilled and semi-skilled manpower in the world of work [16]. Therefore, TVET lecturers teaching in technical colleges plays a vital role in the development of the nation because they are committed toward the development of people by orientating individuals into the world of work, helping them to acquire employable skills, encouraging them not to remain idle in order to reduce the volume of poverty in the society. However, the needs for the Government to invest in education by providing all the necessary needs of TVET lecturers teaching in technical colleges and to ensure students learn when they go to school in order to achieve the desired objective of producing well competent and motivated lecturers [23].

Indeed, the prospect of competent TVET lecturers will bring about the needed manpower development in related field of science and technology and it will advance the career opportuni- ties by producing competent lecturers who will develop great dynamic economic growth and development [20]. Therefore, it could then be argued that the competent TVET lecturer means a TVET lecturer with sufficiency of skills, knowledge, attitude or behaviour. By extension these attributes can be regarded as competency.

\section{An Overview on Competency Model Perceived from Workplace}

The word competency come from Latin word competere which literally means competent, competence or expertise that means individual to have quality or physical and intellectual qualification in carrying out specific task or job [32]. Therefore, competency is the ability and capability of TVET lecturer teaching in technical colleges to possess required knowledge, skills and attitude in order to perform a task assign to him/her. Competency was popularized first by [15] and it was adapted by different researchers in different fields of studies giving it different perceptions or meanings in their fields based on the context in which it was applied [32].

For more than three decades, the term 'Competency' is defined by different researchers with different perceptions and perspectives and in different ways. Based on the definitions given by different researchers, this will help the reader to comprehend and also to see the perception of the researcher is similarly the same with that of other researchers. They defined competency in their own research. According to [18] defined competency as a centre for knowledge or skills that is so vital in producing key outputs. R. Boyatzis [6] viewed competency as the capability and ability of individual skills, knowledge and behaviour to complete the task assigned to them. While [28] defined competency as a combination of component of skills and knowledge required by workers in order to perform their job effectively and efficiently. Researchers [38] on the other hand, posit that competency comprises a collection of skills, knowledge and behaviour that are practice for self-development. Therefore, competency is the ability of TVET lecturer teaching in technical colleges to be capably, competently and adequately in possession of required skills and knowledge, behaviour and abilities that can successfully performed serious task or job as required in the defined setting.

Furthermore, the word competency was firstly discussed and assessed by [17] in the early 1970, 
as a significant forecasters of employee performance and success which is relatively important as a person's academic ability and knowledge as indicated by examination or test results or scores. The person that conducted the first research on competency and came out with the human resource development (HRD) model for American society for training and development (ASTD) opined that competency is an area of skills and knowledge that is so vital for making or producing key output [18]. Although, ASTD argued that Walker and Pinto were the first to conduct HRD competency study in 1978. Similarly [3] posited that Walker and Pinto carried out a study called "A study of professional training and development roles and competencies" that was first sponsored and published by ASTD in 1978 from then competencies became one of the main apparatus applied in measuring, examining or evaluating workers performance in the real world of work situations or environments especially in HRD [9]. However, HRD is the way forward to organisations in order to address the development of workplace competencies [8].

Recently, competencies have become primary source of institutions in terms of evaluating the employee's skills and abilities. It has become one of the review instrument of measuring and evaluating proficiency in soft and hard skills of workers [8]. However, competencies of workers are very vital instrument in determining institutional development and it has been proven to be an instrument to improve TVET lecturers and institutional performance that concentrate on individual's performance [30]. Moreover, the performance of persons, individuals or lecturers are more related to the workplace performance while doing job or task assign to them [32]. Nevertheless, competency needs to be look into as something that represents the entire performance of institution and it's not only concentrate on the organisational performance but is also with the individual performance [19]. However, the individuals or organisations need to be evaluated and modified [32]. Therefore, organisations can be a workplace, tertiary institutions or technical college where the individuals or TVET lecturers work in order to earn their living. Generally, there are two types of competencies, individual and organisational competencies.

\section{Individual competencies}

Individual competency basically is more related to the features of individual which she or he can be trained, instructed, conditioned, indoctrinated, taught and contribute to workplace activities [14]. Therefore, it is important to know that some of the aspects of competency are knowledge, attitude and skills that are matched to solve certain assignment for TVET lecturers in the institutions. Similarly, authors [25] demonstrate that competencies shows person's occupational or professional competence. According to [27, 7] there are competencies that are required for all workers or TVET lecturers which include knowledge, ability and skills as well as core skills. Therefore, any individual that possess the aforementioned competencies may definitely end up applying such competencies in the workplace, institutions or organisations. However, this research will only concentrate or emphasize on organisational competencies.

\section{Organisational Competencies}

Organisational competencies are those features of organisations that bring about the quality in the world of work [14]. The main aim of competencies in organisations is to authenticate the skills levels of workers in order to recognize new combination of skills and knowledge that need to be transferred to the workplace. Hence organisations necessitates higher competency levels of skills and knowledge that can easily respond to the specific requirements within the professional practices [33]. Therefore, the purpose of organisation or institution is to apply competency in order to facilitate the process of assessing the suitability and expertise of its employees or lecturers in completing the task assigned to them. The constructs of this study can be categorized into three namely: organisational competencies, thinking competencies and application competencies [29].

\section{Organisational Competencies as main competencies}

Organisational Competencies can be categorizes into ten such as identification of Critical Business Issues, Communication, Group Dynamics, Work Environment Analysis, Goal Implementation, Buy-in/ Advocacy, Consulting, Negotiating/ Contracting, Systems Thinking, Visioning.

\section{Thinking Competencies}

Thinking competencies are also more related to knowledge and skills [28]. They still maintained that it is the combination of skills and knowledge 
that help workers to perform their duties effectively and efficiently in organisation. Therefore, thinking competencies are the most effective in terms of supporting long term plans in regards to the worker's career development process and professionalism in an organisation. Thinking competencies can also help workers to create, develop, initiate, process and generate good ideas or approach that can shape the organisation [29]. Thinking competencies can be categorize as Workplace performance, learning strategies and intervention evaluation, Competency identification, Facilitation, Standard identification, Questioning, Model building, Analytical thinking and Leadership [29].

\section{Application Competencies}

Application competencies as the name implies is more or less about behaviours and attitudes of individual workers that can be applied in the workplace. These competencies will help the individual workers to realize and understand the needed attitude, values, morale and behaviour required by them to apply in the organisation [29]. Similarly, authors [36] posited that a set of competencies which are more related to behaviour and attitude of workers can easily influence the main aspect of job in organisation by applying such competencies. The application competencies can be categorize as: staff selection, theory and application, training theory and application, feedback, reward system theory and application, organisational development theory and application, career development theory and application and process consultation [29].

\section{Application of Malaysian Human Resource Development Practitioners (MHRDP) Competency Model for Workplace Learning and Performance in Technical Colleges of Bauchi State}

There is needs for technical colleges to improve the strength of TVET lecturer's competencies. This can be accomplished by adopting and adapting the MHRDP competency model developed by [29]. Although the MHRDP competency model for workplace learning and performance (WPL) is a product of ASTD for WPL that have been in existence for so many years and it has 52 different indicators of competencies developed by [27]. The competency model has been shown to undergo several reviews over the years since its development [10].

Many institutions are adopting and adapting competency model in order to develop and achieve their needs and goals [2]. Therefore, the model also needs to work in line with the technical colleges policies and vision because it will test the TVET lecturers competencies and it will be used as platform for the technical colleges to realize the best plan for current and future development of the TVET lecturers. Devoting to improve the competency level is one of the most powerful ways to prove to the lecturers that they are honourably valued, respected and trusted [5].

\section{Conceptual framework}

Figure 1 present the proposed conceptual framework of this research which is adapted from [29] based on the Malaysian Human Resource Development Practitioners (MHRDP) Competency Model for Work Place Learning and performance (WLP).

\begin{tabular}{|c|c|c|}
\hline $\begin{array}{l}\quad \text { Organizational } \\
\text { 1. Identification of Critical } \\
\text { Business Issue } \\
\text { 2. Communication } \\
\text { 3. Group Dynamics } \\
\text { 4. Work Environment Analysis } \\
\text { 5. Goal Implementation } \\
\text { 6. By-in-Advocacy } \\
\text { 7. Consulting } \\
\text { 8. Negotiating / Contacting } \\
\text { 9. Systems Thinking } \\
\text { 10. Visioning }\end{array}$ & $\begin{array}{l}\quad \text { Thinking } \\
\text { 1. Workplace performance, } \\
\text { learning strategies and } \\
\text { intervention evaluation } \\
\text { 2. Competency identification } \\
\text { 3. Facilitation } \\
\text { 4. Standard identification } \\
\text { 5. Questioning } \\
\text { 6. Model building } \\
\text { 7. Analytical thinking } \\
\text { 8. Leadership }\end{array}$ & $\begin{array}{l}\quad \text { Application } \\
\text { 1. Staff selection theory and } \\
\text { application } \\
\text { 2. Training theory and } \\
\text { application } \\
\text { 3. Feedback } \\
\text { 4. Reward system theory and } \\
\text { application } \\
\text { 5. Organisational development } \\
\text { theory and application } \\
\text { 6. Career development theory } \\
\text { and application } \\
\text { 7. Process consultation }\end{array}$ \\
\hline$\frac{1}{7}$ & $\downarrow$ & $\downarrow$ \\
\hline
\end{tabular}

Figure 1 - Propose Conceptual Framework; adapted from [29] 
The original MHRDP model contains twenty five indicators of competencies which were classified into three groups of competency which are main competencies, sub competencies 1 and sub competencies 2. The aim of this conceptual framework is to propose and describe the recent direc- tion of TVET lecturers teaching in technical colleges by investigate the suitable items of competencies which are related to the technical colleges based on this groupings. Table 1 below shows the items of competencies.

Table 1 - Three Competency Groups and Associated competencies

\begin{tabular}{|c|c|c|}
\hline Competency Group & Competency Description & Source \\
\hline $\begin{array}{l}\text { Organisational } \\
\text { Competency }\end{array}$ & $\begin{array}{l}\text { Identification of Critical Business Issue } \\
\text { Communication } \\
\text { Group Dynamics } \\
\text { Work Environment Analysis } \\
\text { Goal Implementation } \\
\text { Buy-in-Advocacy } \\
\text { Consulting } \\
\text { Negotiating/ Contracting } \\
\text { Systems Thinking } \\
\text { Visioning }\end{array}$ & $\begin{array}{l}8,14,19,27, \\
29\end{array}$ \\
\hline Thinking Competency & $\begin{array}{l}\text { Workplace performance, learning strategies and intervention } \\
\text { evaluation } \\
\text { Competency identification } \\
\text { Facilitation } \\
\text { Standard identification } \\
\text { Questioning } \\
\text { Model building } \\
\text { Analytical thinking } \\
\text { Leadership }\end{array}$ & $27,28,29,33$ \\
\hline Application Competency & $\begin{array}{l}\text { Staff selection theory and application } \\
\text { Training theory and application } \\
\text { Feedback } \\
\text { Reward system theory and application } \\
\text { Organisational development theory and application } \\
\text { Career development theory and application } \\
\text { Process consultation }\end{array}$ & $27,29,36$ \\
\hline
\end{tabular}

The propose conceptual framework of this study show the relationship between the main competencies group and sub competencies groups thus, organisational competencies as main, thinking competencies and application competencies as sub competencies 1 and 2 . The three groups of competencies can be regarded as the combination of skills, knowledge and attitude or behaviour to be acquired by TVET lecturers teaching in technical colleges of Bauchi State in order to produce competent TVET lecturers in technical colleges.

\section{MATERIAL AND METHOD}

This research is purely quantitative and survey strategy was used, one of the most significant in- strument to be use in such a research is questionnaire, it is a widely used instrument for data collection in survey strategy [20]. Therefore, questionnaire instrument was used in this study which consist of personal and demographic details of respondents which is filled and returned to the researcher [1].

The sample of this research is 30 TVET lecturers teaching in technical colleges of Bauchi State (University, Polytechnics and College Education) as the respondents because the minimum number of instrument to conduct a pilot study is $\mathbf{3 0}$ [12]. The stratified sampling technique has been used. The position of the respondents participated in the survey 1 Dean, 2 Head of section, 3 Programme Coordinators, 8 Head of Department and 16 Lecturers. Similarly, educational qualification of the respondents are 3 Doctoral, 9 Bache- 
lors and 18 Master's degree respectively. The ages ranging from 26 to 65 years and out of which 5 Female and 25 Male.

\section{Expert validation for instrument}

The draft of the instrument was sent to the four experts (two experts from the University, one from Polytechnic and the other one from College of Education) in order to assess the content validity of the instrument and its appropriateness in the contest of the problems under examination. The instruments were with experts for a good one month and they made all the necessary observations and corrections which has been well noted and corrected.

\section{RESULT AND DISCUSSION}

Reliability of pilot test results shows in the Table 2 .

Table 2 - Reliability of pilot test results

\begin{tabular}{|c|c|c|c|}
\hline Code & Label & Cronbach's Alpha if item deleted & Scale's Cronbach's Alpha \\
\hline COM1 & Skill & $.518^{*}$ & \multirow{3}{*}{.612} \\
\hline COM2 & Knowledge & $.330 *$ & \\
\hline COM3 & Attitude & $.433^{*}$ & \\
\hline ORG1 & Critical & .698 & \multirow{10}{*}{.722} \\
\hline ORG2 & Communication & .723 & \\
\hline ORG3 & Group dynamics & .736 & \\
\hline ORG4 & Work environment & .726 & \\
\hline ORG5 & Goal implementation & .714 & \\
\hline ORG6 & Buy in & .641 & \\
\hline ORG7 & Consulting & .679 & \\
\hline ORG8 & Negotiating & .710 & \\
\hline ORG9 & System thinking & .635 & \\
\hline ORG10 & Visioning & .712 & \\
\hline THI1 & Workplace & .603 & \multirow{8}{*}{670} \\
\hline THI2 & Competency identification & .620 & \\
\hline THI3 & Facilitation & .671 & \\
\hline THI4 & Standard identification & .669 & \\
\hline THI5 & Questioning & .673 & \\
\hline THI6 & Model building & .605 & \\
\hline THI7 & Analytical thinking & .640 & \\
\hline THI8 & Leadership & .625 & \\
\hline APP1 & Staff selection & .692 & \multirow{7}{*}{.696} \\
\hline APP2 & Training theory & .663 & \\
\hline APP3 & Feedback & .716 & \\
\hline APP4 & Reward system & .669 & \\
\hline APP5 & Institutional development & .613 & \\
\hline APP6 & Career development & .602 & \\
\hline APP7 & Process consultation & .656 & \\
\hline
\end{tabular}

Notes: values with * is Corrected Item-Total Correlation

The consistency of the questionnaire scales were tested using the Cronbach's Alpha method. The recommended threshold for scale reliability is 0.70 and above. Although 0.60 can also be regarded as acceptable when the research is at its exploratory stage. Moreover, another vital statistics usually examined is the corrected item-total correlation. This measures the internal consistency of the scale and value of 0.30 and above is recommended [13]. 
Table 1 shows the result of the reliability analysis. The reported Scale's Cronbach's Alphas indicated that all the scales are reliable. The Organisational Competencies reported the highest alpha value $(\alpha=0.722)$ with Cronbach's Alpha if item deleted ranging from 0.635 to 0.736 . The next highest alpha values are Thinking Competencies $(\alpha=0.696)$, with Cronbach's Alpha if item deleted ranging from 0.602 to 0.716 . Application Competencies $(\alpha=0.670)$ with Cronbach's Alpha if item deleted ranging from 0.603 to 0.673 , and the TVET teachers Competencies $(\alpha=0.612)$ with corrected item-total correlations ranging from $0.330^{*}$ to $0.518^{*}$ The Cronbach's Alpha if item deleted in respect of these scales range from 0.670 to 0.722 , related to SPA and IB respectively. The reported alpha values and the corrected item-total correlations of the scales also satisfy the acceptable threshold of 0.70 or 0.60 and 0.30 respectively. Therefore, it could be concluded that the questionnaire scales are reliable and could be useful in measuring what it is intended to measure.

\section{CONCLUSION}

The proposed competency model for TVET lecturers teaching in technical colleges of Bauchi State in perspective in this paper is now presented. Therefore, it could be concluded that the questionnaire scales are reliable and could be useful in measuring what it is intended to measure. This paper is limited to only publish articles that were accessible during this work. However, this established the limitation of this work and therefore the interpretation of this model.

\section{REFERENCES}

1. Agrawal, T. (2013). Vocational education and training programs (VET): An Asian perspective. AsiaPacific Journal of Cooperative Education, 14(1), 15-26.

2. Berge, Z., de Verneil, M., Berge, N., Davis, L., \& Smith, D. (2002). The increasing scope of training and development competency. Benchmarking: An International Journal, 9(1), 43-61. doi: $10.1108 / 14635770210418579$

3. Bernthal, P. R. (2004). ASTD 2004 competency study: Mapping the Future. Alexandria: American Society for Training \& Development.

4. Billett, S. (2001). Learning in the workplace: Strategies for effective practice. Crows Nest: Allen \& Unwin.

5. Black, D. A. (2001). Creating strategic plans with the power to win. Strategy \& Leadership, 29(1), 2732. doi: $10.1108 / 10878570110367150$

6. Boyatzis, R. E. (2008). Competencies in the 21st century. Journal of Management Development, 27(1), 5-12. doi: 10.1108/02621710810840730

7. Buntat, Y., Saleh, N. M., Musban, M., Musta'amal@Jamal, A. H., Saud, M. S., \& Nor, F. M. (2013). Competency-Based Education: A Case of Akademi Binaan Malaysia. Procedia - Social and Behavioral Sciences, 93, 1536-1540. doi: 10.1016/j.sbspro.2013.10.078

8. Conlon, T. J. (2004). A review of informal learning literature, theory and implications for practice in developing global professional competence. Journal of European Industrial Training, 28(2/3/4), 283-295. doi: 10.1108/03090590410527663

9. Dean, P. J., Dean, M. R., \& Rebalsky, R. M. (2008). Employee Perceptions of Workplace Factors That Will Most Improve Their Performance. Performance Improvement Quarterly, 9(2), 75-89. doi: 10.1111/j.1937-8327.1996.tb00721.x

10. Dubois, D., \& Rothwell, W. (2004). Competency-Based Human Resource Management: Discover a New System for Unleashing the Productive Power of Exemplary Performers. New York: Nicholas Brealey Publishing.

11. The Federal Republic of Nigeria. (2013). National policy on education (6th ed.). Lagos: NERDC.

12. Fink, A. (2014). Conducting research literature reviews: From the Internet to Paper (4th ed.). Los Angeles: Sage. 
13. Fogg, C. D. (1999). Implementing your strategic plan: How to turn" Intent" into effective action for sustainable change. Washington DC: AMACOM.

14. Garavan, T. N., \& McGuire, D. (2001). Competencies and workplace learning: some reflections on the rhetoric and the reality. Journal of Workplace Learning, 13(4), 144-164. doi: $10.1108 / 13665620110391097$

15. Hamel, G., \& Prahalad, C. K. (1990). Corporate imagination and expeditionary marketing. Harvard Business Review, 69(4), 81-92.

16. Hanimastura, H., Hairulliza M. J., Tengku, S. M, \& Tengku, W. (2016). Success factors for knowledge sharing among TVET instructors. Journal of Theoretical and Applied Information Technology, 85(1), 12-20.

17. McClelland, D. C. (1998). Identifying Competencies with Behavioral-Event Interviews. Psychological Science, 9(5), 331-339. doi: 10.1111/1467-9280.00065

18. McLagan, P. (2002). Change is everybody's business. N. d.: Berrett-Koehler Publishers.

19. Morningstar, M. E., Kim, K.-H., \& Clark, G. M. (2008). Evaluating a Transition Personnel Preparation Program: Identifying Transition Competencies of Practitioners. Teacher Education and Special Education: The Journal of the Teacher Education Division of the Council for Exceptional Children, 31(1), 47-58. doi: 10.1177/088840640803100105

20. Njati, C. (2016). Planning and managing technical and vocational education in polytechnics: Priorities in training trends and prospects. International Journal of Humanities and Social Science Invention, 5(4), 6-18.

21. Okoye, K. R. E., Okwelle, P. C., \& Okoye, P. I. (2015). Enhancement and innovation in higher education in Nigeria through technical vocational education and training (TVET) and entrepreneurship education. Advances in Social Sciences Research Journal, 2(5), 166-174.

22. Okoye, K. R., \& Isaac, M. O. (2015). Enhencing technical and vocational education and training (TVET) in Nigeria for sustainable development: Competency based training approach. Journal of Education and Practice, 6(29), 66-69.

23. Oni, C. S. (2007). Globalization and its implications for vocational education in Nigeria. Essays in Education, 21(1), 30-34.

24. Paloniemi, S. (2006). Experience, competence and workplace learning. Journal of Workplace Learning, 18(7/8), 439-450. doi: 10.1108/13665620610693006

25. Rodriguez, D., Patel, R., Bright, A., Gregory, D., \& Gowing, M. K. (2002). Developing competency models to promote integrated human resource practices. Human Resource Management, 41(3), 309-324. doi: 10.1002/hrm.10043

26. Rothwell, W. J. (1996). Beyond training and development: State-of-the-art strategies for enhancing performance. New York: AMACOM.

27. Rothwell, W. J., Sanders, E. S., \& Soper, J. G. (1999). ASTD models for workplace learning and performance: Roles, competencies, and outputs. Alexandria: American Society for Training and Development.

28. Rycus, J., \& Hughes, R. (2000). What is competency-based In-service training? Retrieved from http://www.narccw.com/TRAINet/Resource\%20Paper\%201.pdf

29. Salleh, K. M. (2012). Human resource development practitioners perspectives on competencies: An application of American Society for Training and Development (ASTD) Workplace Learning and Performance (WLP) competency model in Malaysia (Doctoral dissertation). Retrieved from http://hdl.handle.net/10217/71571

30. Salleh, K. M., \& Sulaiman, N. L. (2013). Malaysia leadership competencies: A model for effective performance. International Journal of Human Resource Management and Research, 3(2), 63-70. 
31. Salleh, K. M., Sulaiman, N. L., \& Frederiksen, H. (2014). Comparison of teacher licensing between the united states of America and Malaysia: Implementation and practical implication. Education Journal, 3(3), 190-194.

32. Salleh, M. K., Lisa Sulaiman, N., \& W. Gloeckner, G. (2015). The Development of Competency Model Perceived by Malaysian Human Resource Practitioners' Perspectives. Asian Social Science, 11(10). doi: 10.5539/ass.v11n10p175

33. Sauber, M. H., McSurely, H. B., \& Rao Tummala, V. M. (2008). Developing supply chain management program: a competency model. Quality Assurance in Education, 16(4), 375-391. doi: 10.1108/09684880810906517

34. Schulze, U., Gryl, I., \& Kanwischer, D. (2014). Spatial citizenship: Creating a curriculum for teacher education. GI_Forum 2014 - Geospatial Innovation for Society. doi: 10.1553/giscience2014s230

35. Spöttll, G. (2009). Teacher education for TVET in Europe and Asia: The comprehensive requirements. Journal of Technical Education and Training, 1(1), 1-16.

36. Suhairom, N., Musta'amal, A. H., Amin, N. F. M., \& Johari, N. K. A. (2014). The Development of Competency Model and Instrument for Competency Measurement: The Research Methods. Procedia - Social and Behavioral Sciences, 152, 1300-1308. doi: 10.1016/j.sbspro.2014.09.367

37. Sulaiman, N. L., Mohd Salleh, K., Mohamad, M. M., \& Chee Sern, L. (2015). Technical and Vocational Education in Malaysia: Policy, Leadership, and Professional Growth on Malaysia Women. Asian Social Science, 11(24). doi: 10.5539/ass.v11n24p153

38. Tripathi, K., \& Agrawal, M. (2014). Competency based management in organization. Global Journal of Finance and Management, 6(4), 349-356. 